\title{
Highlights
}

- Two areas of high tidal stream exergy are identified in the Ria de Vigo region.

- The energy output of two TEC farms, based on different turbines, is estimated.

- $15 \%$ of the $22.5 \mathrm{MW}$ hourly extractable power per site can be tapped by the farms.

- The estimated power output is between.

- Depending on the used TEC, the farms can feed between 4411 and 6638 Spanish homes. 


\section{Analysis of the optimal deployment location for tidal energy converters in the mesotidal Ria de Vigo (NW Spain)}

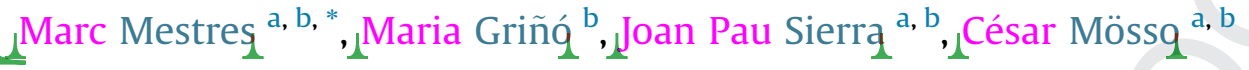

a International Centre for Coastal Resources Research (CIIRC), c/Jordi Girona 1-3, Mòdul D1, 08034 Barcelona, Spain

b Laboratori d'Enginyeria Marítima (LIM-UPC), Universitat Politècnica de Catalunya-BarcelonaTech, c/Jordi Girona 1-3, Mòdul D1, 08034 Barcelona, Spain

\section{A R T I C L E I N F O}

\section{Article history:}

Received 23 February 2016

Received in revised form

2 May 2016

Accepted 11 June 2016

Available online $\mathrm{xxx}$

\section{Keywords:}

Tidal stream energy

Resource assessment

Tidal farm design

Ria de Vigo

\begin{abstract}
A B S T R A C T
The potential power output expected from the installation of a tidal farm near the mesotidal Ria de Vigo (NW Spain) is assessed using two different tidal stream energy converters (TEC). For this, the results of a previous resource assessment based on a 28-day long hydrodynamic simulation are used. From this data we identify the areas susceptible of hosting the farms, select the optimal location for them, and assess the total available and extractable energy for each turbine type. Finally, using a simple farm design based on standard inter-turbine separation, we estimate the expected power supplied by the farm. Irrespective of the site, the total available tidal power in the areas susceptible of hosting the farms is around $150 \mathrm{MW}$; at the optimal location, the hourly extractable power is about $22.5 \mathrm{MW}$, of which only between $10 \%$ and $15 \%$ can be harnessed by the designed farms, powering between 4411 and 6638 homes. A local analysis of the most energetic subregions within these sites increases this ratio up to $30 \%$. Nevertheless, the power output is sufficient to fulfil the needs of between 1660 and 2213 households, depending on the chosen site and the selected TEC.
\end{abstract}

๑) 2016 Elsevier Ltd. All rights reserved.

\section{Introduction}

The sustained growth in energy demand expected in the near future (37\% by 2040 [1]), the depletion of fossil fuel reserves [2] and the raising concern for the effects on global climate change of fossil fuels (e.g. [3]) has increased the interest for the exploitation of renewable energy sources. Amongst these, one of the most promising is undoubtedly linked to the highly predictable and periodical tidal currents [4]. Although the principles behind wind and tidal stream energy extraction are the same, the higher density of seawater as compared to air assures that the power generated by tidal energy conversion devices is much larger than that generated by a wind energy converter under similar conditions.

Tidal stream resources have been assessed worldwide in the last years, and key areas have been identified. For instance [5], quantified the tidal energy potential in the Kennebec estuary in the USA [6], and [7] estimated the tidal stream power in the Severn estuary and in the Pentland Firth (UK) respectively, and [8] or [9] assessed

* Corresponding author. International Centre for Coastal Resources Research (CIIRC), c/Jordi Girona 1-3, Mòdul D1, 08034 Barcelona, Spain.

E-mail address: mmestresridge@gmail.com (M. Mestres). this resource in Fundy Bay (Canada) and Norway respectively. Countries like Iran [10], China [11] or Korea [12] have also evaluated the tidal resource at different locations along their coasts. In the particular case of Spain, studies analyzing the potential for tidal stream energy tapping have been focused mostly on its mesotidal Atlantic coast ([13-15]).

The power supplied by a tidal energy extraction farm does not only depend on the available energetic resource, but is modulated by several technological, environmental and economic factors. Financially speaking, the development of a tidal stream energy converter (TEC) farm involves a huge investment. For example, the estimated cost per turbine in the set of EPRI reports analyzing different prospective tidal energy farm sites in the USA [16] ranges from 1 to 2.25 million US\$; the single turbine deployed at Race Rocks (Canada) required a 4 million US\$ investment [17], whereas the SeaGen converter installed in Ireland costs about 11 million US\$ [18]. The design of a tidal stream farm must take all these aspects into account in order to optimize its power output.

On the other hand, environmental concerns limit the fraction of available energy that can be extracted without incurring in significant alteration of the environment. It has been shown that tidal energy extraction can lead to changes in the tidal range, dispersion 
and transport patterns, water quality [19], sediment and erosion patterns [20] or even in the wave energy regime, depending on the particular wave-current interaction [21]. [19] found that the effects of a tidal farm on suspended sediment concentrations could extend as far as $15 \mathrm{~km}$ downstream. Other effects include adjustments in salinity and nutrient distributions, changes in benthic habitats, toxicity associated to paint, antifoulants and lubricants, interference with animal movements ([22,23]), or even long-term changes to biological population and communities [24]. To minimize these effects [25], suggested introducing a Significant Impact Factor (SIF), defined as the percentage of the total resource at a site that can be extracted without significant environmental impact.

The extracted power depends also on the extraction devices and their distribution within the farm array. Each TEC is designed and built to respond in a particular manner to different flow speeds; its power curve determines the power output as a function of the tidal current speeds [26]. Furthermore, the density of turbines within a farm affects the economic viability of the installation, since the spacing between converters is a key element in determining the overall performance of the turbine array. Narrow lateral spacing might result in negative interaction between converters, such as reduced power output or increased thrust forces [27], whereas large spacing leads to an inefficient use of space. Optimal lateral spacing might even accelerate the flow between turbines [28], increasing the production of downstream devices. [29] proposes a lateral spacing between turbines of 2.5 times their diameter, which is the value considered here. On the other hand, the wake effects and the flow speed reduction on the lee side of a tidal energy converter determine the downstream separation between devices [28]; found flow velocity deficits up to ten rotor diameters downstream of the generator. The grouping of several turbines into an array becomes a balance of maximizing the total power output while minimizing the input on the natural flow [30].

In this paper, the results for the Ria de Vigo presented in Ref. [15] are used, together with the above considerations, to determine the best location for the installation of a tidal stream energy farm in the area. Following this, the expected power output of such a farm with a minimum impact on the environment is assessed, based on a simple turbine distribution and using two different energy converter devices with a publicly available power curve.

\section{Study site}

The Ria de Vigo (Fig. 1) is the southernmost of the four Rías Baixas, located in the Northwestern Spanish Atlantic coast. It stretches approximately $32 \mathrm{~km}$ in a rough NE-SW direction, with an external width of $10 \mathrm{~km}$ and a depth in its central part of about $26 \mathrm{~m}$, which decreases rapidly towards the banks [31]. This Ria covers an area of about $185 \mathrm{~km}^{2}$, and has a volume capacity slightly larger than $3250 \mathrm{H} \mathrm{m}^{3}$, this yields a surface/volume ratio of 0.05 , typical of V-shaped estuaries [32].

The waterbody is connected to the Atlantic Ocean through three channels defined by the presence of the Cíes Islands at the estuary mouth. The northern channel is around $2.5 \mathrm{~km}$ wide, with a maximum depth of $23 \mathrm{~m}$, while the southern mouth is wider and deeper ( $5 \mathrm{~km}$ and $52 \mathrm{~m}$, respectively), and the central channel, separating both islands, is narrower and shallow [33].

Circulation patterns in the estuary are strongly conditioned by the semidiurnal mesotides [34], by the wind regimes on the continental shelf and in the ria itself, and by the freshwater discharge of the Oitabén-Verdugo river system. The shallow and wide basin at the estuary head is dominated by riverine output and currents induced both by the tide and the local wind, whereas the area closest to the mouth (between the Cíes Islands and the line joining Mar Cape and Borneira Tip) is influenced mostly by tidal currents and flows driven by the wind blowing over the continental shelf. In between, the currents in the central stretch might be driven by any or all of the aforementioned forcings.

Astronomical tides constitute the principal contribution to the sea level variations in this area, with a range varying between $0.82 \mathrm{~m}$ and $4.21 \mathrm{~m}$, and a mean value of $2.4 \mathrm{~m}$. These are much larger than typical storm surges, although surge values of $-1.08 \mathrm{~m}$ and $0.69 \mathrm{~m}$ have been observed during the 1992-2009 period [35].

\section{Methodology}

\subsection{Tidal stream exergy}

The tidal stream exergy for the Ria de Vigo has been estimated previously [15] from the results of a 28 day long numerical simulation using a 3D hydrodynamic model forced at the boundaries exclusively by tidal sea levels and currents. The results found

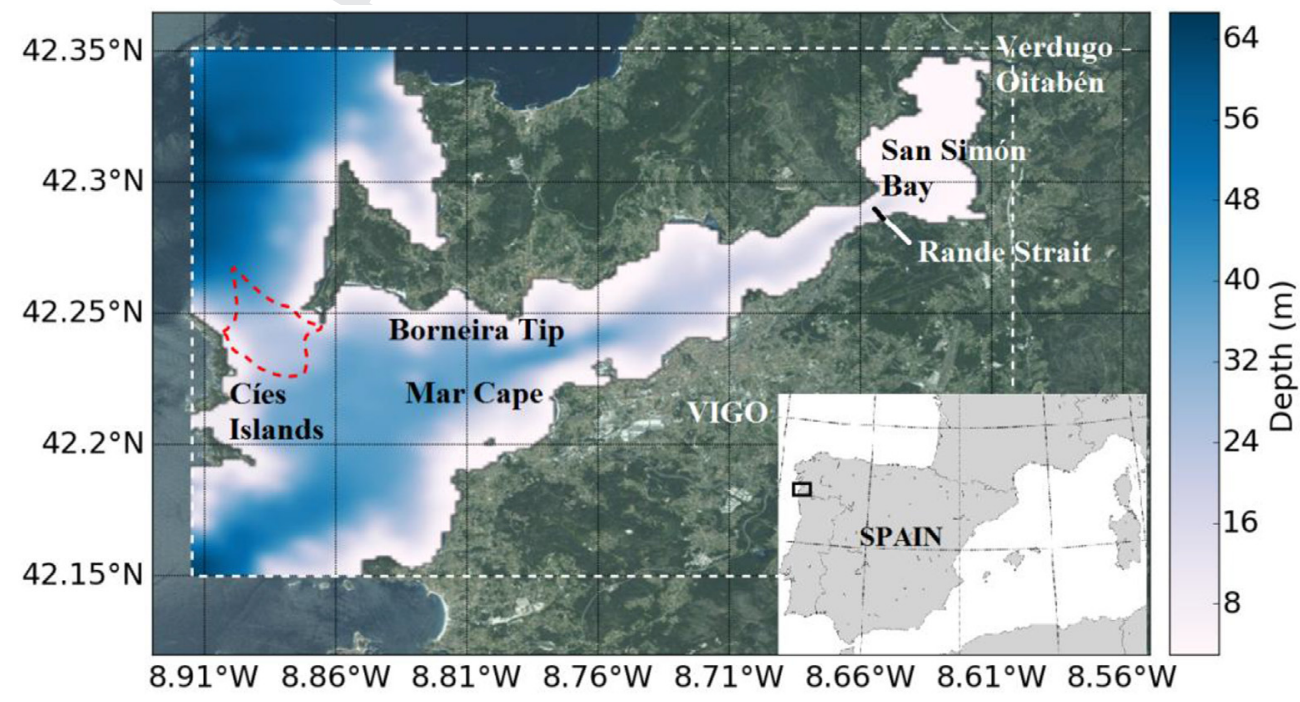

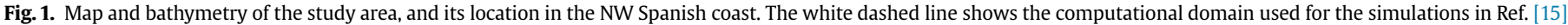

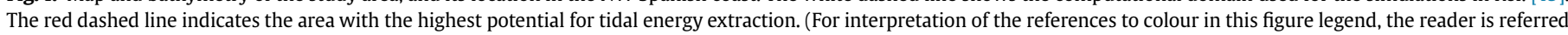
to the web version of this article.) 
therein are used in this paper to compare the power output supplied by a tidal energy converter farm based on two different types of generators.

In spite of the flow being mostly tidally-driven [15], showed that the exergy of the tidal stream within the estuary is too small to be extracted under the actual technological conditions. Inside the Ría, tidal currents seldom reach $1 \mathrm{~m} / \mathrm{s}$, which is the minimum threshold proposed by Ref. [36] for feasible tidal energy harnessing. However, the same study identified a $7.5 \mathrm{~km}^{2}$ area outside the estuary, in the strait between the northern Cíes island and the mainland (Fig. 1), in which the average power density exceeds the minimum value of $0.5125 \mathrm{~kW} / \mathrm{m}^{2}$ corresponding to the $1 \mathrm{~m} / \mathrm{s}$ threshold. Thus, it presents a significant potential for tidal stream exploitation. The total theoretically available power density for this area has been estimated at around $3865 \mathrm{MWh} / \mathrm{m}^{2}$ per annum [15], which is higher than the resource estimated by Refs. [13] and [37] in the nearby Ria de Muros and the Ria de Ribadeo, respectively, both along the NW Spanish coast.

\subsection{Tidal in-stream energy converters}

Two tidal stream energy converters with an available power curve have been considered in this work: the Rotech Tidal Turbine (RTT2000) by Lunar Energy, and the SeaGen-S generator by Marine Current Turbines. These devices have been selected after evaluating the characteristics (e.g., installation depth or rated speed) and availability of the power curves of 18 devices [38], and their suitability for this study case.

The RTT200 is a horizontal axis generator with a symmetrical Venturi duct (Fig. 2, left) that guides the flow to the central turbine from a wide range of directions while increasing the current speed, thus eliminating the need for a yaw control system. The generator is placed on a gravity base (i.e., kept in position by its own weight) that lifts the device about $7 \mathrm{~m}$ above the bed. The diameter of the duct is $25 \mathrm{~m}$, with $7.8 \mathrm{~m}$ long blades and a $3.9 \mathrm{~m}$ central hub. With these dimensions, and granting a $5 \mathrm{~m}$ top clearance, the minimum water depth that allows the installation of this converter is $37 \mathrm{~m}$. The configuration used herein supplies $2 \mathrm{MW}$ at a rated speed of $3.1 \mathrm{~m} / \mathrm{s}$, with a $1 \mathrm{~m} / \mathrm{s}$ cut-in velocity [39].

On the other hand, the SeaGen-S converter incorporates twin horizontal axis rotors mounted on a crossbeam supported by a surface-piercing tubular steel tower (Fig. 2, right). Each rotor is $20 \mathrm{~m}$ in diameter, providing a total swept area of $628 \mathrm{~m}^{2}$, and relies on blade pitching for flood and ebb production [40]. With a $5 \mathrm{~m}$ clearance at the top and at the bottom, the minimum water depth possible for this type of converter is about $31 \mathrm{~m}$. The SeaGen-S has a cut-in tidal speed of $1 \mathrm{~m} / \mathrm{s}$, and a $2 \mathrm{MW}$ rated power at $2.5 \mathrm{~m} / \mathrm{s}$ flow velocity. According to the developer [41], the device is suitable for marine environments in water depths up to $38 \mathrm{~m}$.

The main characteristics of each converter are summarized in Table 1 . The respective power curves, extracted from Ref. [39] for the RTT2000 turbine and from Ref. [42] for the SeaGen-S converter, are shown in Fig. 3. These curves provide an indication of the turbine efficiency, taking into account Betz's limit and the exergy that is destroyed during the energy conversion process (mostly in the form of heat [43]), as a function of the tidal current speed.

\subsection{Tidal farm configuration}

The design of a tidal energy farm must take into account several factors, such as the maximum installable number of turbines to maximize the exploitability of the resource, the downstream and lateral separation between turbines, the farm orientation, or the probable environmental impact of the farm.

In order to optimize the capture of tidal stream energy, the tidal farm considered herein is a simple several-row array of turbines, perpendicular to the main direction of the flow (in this case, coincident with the direction of the channel). The separation between both rows is taken as 10 times the diameter of the turbine rotor, as suggested by Refs. [29] and [28], while the inter-turbine lateral separation is 2.5 times the diameter [29]. Although, in general, the lateral spacing could be affected by the yawing motion of the turbines to adapt to the flow from a wide range of directions, neither the RTT2000 nor the SeaGen-S devices include a yaw control system, so this motion is not considered for the determination of the lateral distance between turbines. The total number of turbines per row will depend on the ratio between the total extractable power resource and the expected power output per turbine.

Table 1

Main characteristics of the two tidal energy converters used in this study.

\begin{tabular}{lll}
\hline & RTT2000 & SeaGen-S \\
\hline Diameter $(\mathrm{m})$ & 25 & 20 \\
Total swept area $\left(\mathrm{m}^{2}\right)$ & 490.9 & $628.0^{\mathrm{a}}$ \\
Rated power $(\mathrm{MW})$ & 2 & 2 \\
Rated speed $(\mathrm{m} / \mathrm{s})$ & 3.1 & 2.5 \\
Cut-in speed $(\mathrm{m} / \mathrm{s})$ & 1.0 & 1.0 \\
Minimum water depth $(\mathrm{m})$ & 37 & 31 \\
\hline
\end{tabular}

a Area swept by both rotors.

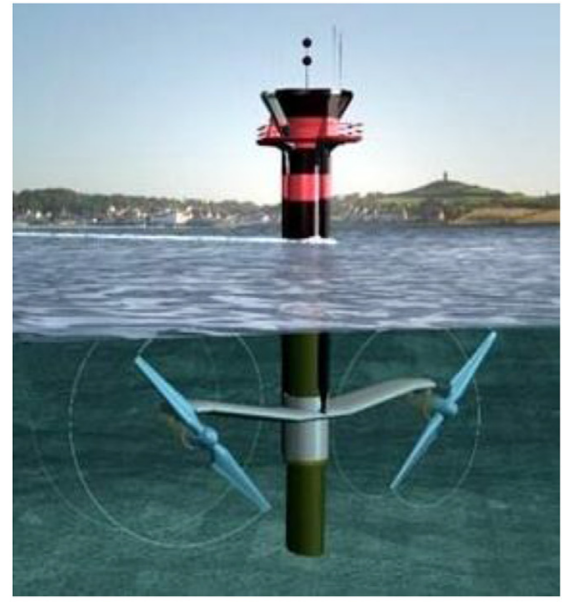

Fig. 2. Tidal in-stream energy converters used in this study: Lunar Energy's RTT2000 (left) and MCT's SeaGen-S (right). 


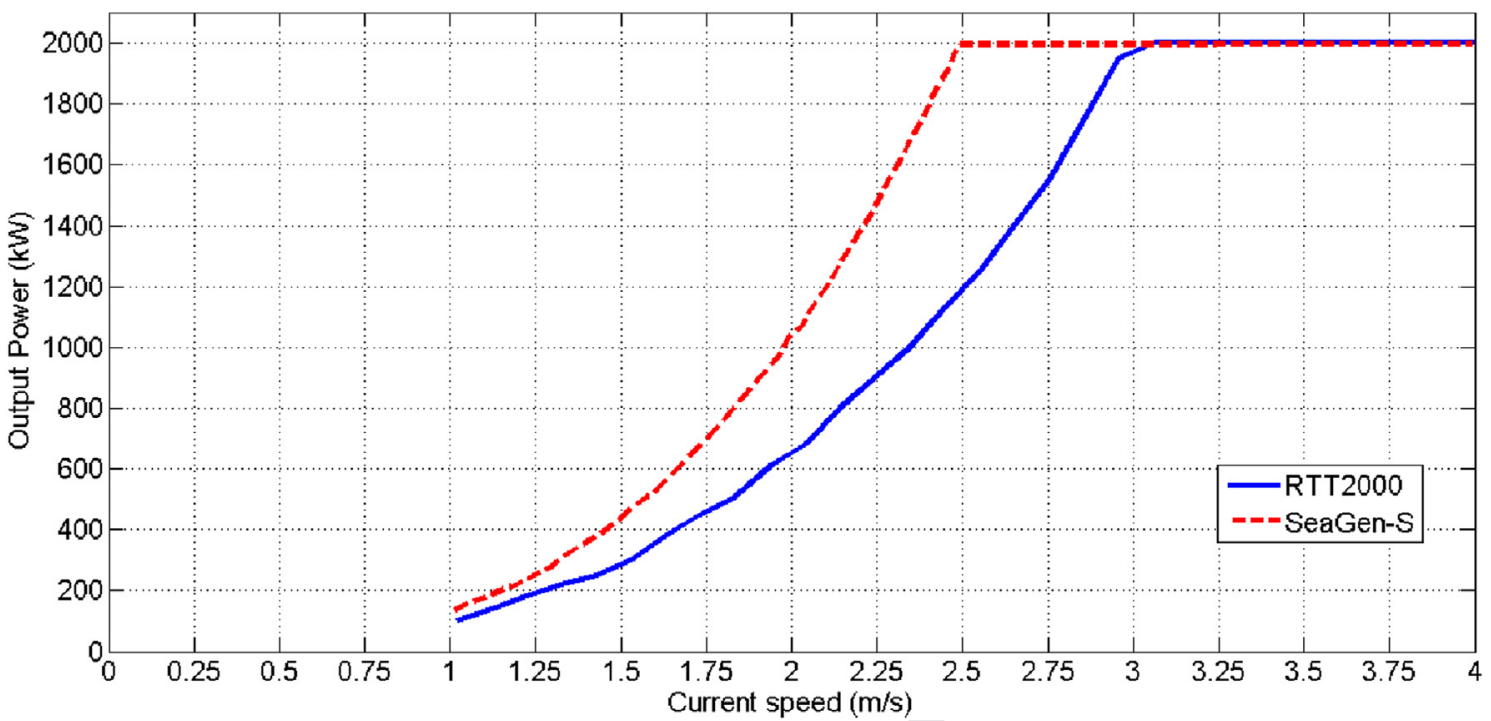

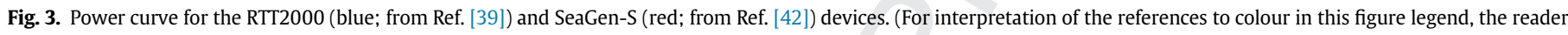
is referred to the web version of this article.)

The extractable energy (i.e., the fraction of the available energy that can be tapped without significant environmental effects) is characterized by the Significant Impact Factor (SIF). The SIF might range between $10 \%$ and $30 \%$, depending on the type of site ([44-46]). Following [47], a SIF of $15 \%$ is adopted in this study.

In turn, the average power density available (APD) for extraction can be calculated from the modelled current time series as

$A P D=\sum_{i=1}^{N_{c}} A P D_{i}=\sum_{i=1}^{N_{c}}\left(\frac{1}{2} \frac{1}{N} \rho \sum_{j=1}^{N} V_{i, j}^{3}\right)=\frac{1}{2} \rho \sum_{i=1}^{N_{c}} V_{i, r m c}^{3}$

where $V_{i, j}\left(i=1, \ldots N_{c} ; j=1, \ldots, N\right)$ is the velocity in cell $i$ at time $t_{j}, N_{c}$ is the number of computational cells in the considered region, $N$ is the number of current data values, and $V_{i, r m c}$ is the respective rootmean-cubed velocity.

$V_{i, r m c}=\sqrt[3]{\frac{1}{N} \sum_{j=1}^{N} \mathrm{~V}_{i, j}^{3}}$

\section{Results and discussion}

The selection of the optimal location to install a tidal energy plant must consider several factors, such as the available average power density, the distance to the coast, and the local water depth, which should allow for the installation of the converter plus suitable top and bottom clearances. Typical clearance values are between 5 and $10 \mathrm{~m}$ near the surface, allowing the passage of most vessels, while the bottom clearance is usually taken as $5 \mathrm{~m}$ or $25 \%$ of the water depth, whichever is largest [29].

With these clearances, the minimum depth required for the deployment of the tidal energy converters restricts the area susceptible of hosting the farm. As can be seen in Fig. 4, a large fraction of the most energetic area identified by Ref. [15] in the channel is unsuitable for the installation of both the RTT2000 and the SeaGen$S$ devices, since the water depth is smaller than $31 \mathrm{~m}$. The deeper zones are located to the north of this area, in which the depth can reach up to $50 \mathrm{~m}$. From the $7.5 \mathrm{~km}^{2}$ originally suggested by Ref. [15] for the development of a tidal energy farm near the Ria de Vigo, only $9 \%\left(0.7 \mathrm{~km}^{2}\right.$, Area 1$)$ is apt for the SeaGen-S converter while $0.65 \mathrm{~km}^{2}$ (i.e., $8 \%$, Area 2) can support the deployment of RTT2000 converters.

Fig. 5 shows the spatial distribution of APD within each of these areas. In both cases, the highest-energy region (delimited by cells $\mathrm{C} 1-\mathrm{C} 4)$ is located at the southeastern end of the site.

Using the numerical results from the 28-day simulation, the total annual energetic potential can be estimated to be 181.11 $\mathrm{MWh} / \mathrm{m}^{2}$ at Area 1 and $139.1 \mathrm{MWh} / \mathrm{m}^{2}$ at Area 2. These values represent approximately $4.6 \%$ and $3.6 \%$ of the total annual potential available in the whole selected region, which was evaluated to be $3865 \mathrm{MWh} / \mathrm{m}^{2}$ by Ref. [15].

The energy that could be potentially generated by an array of tidal energy converters can be determined following the flux method [44], based on the calculation of the incoming kinetic flux through the frontal cross-sectional area of a flow channel within the selected site, and is independent of the device type, packing density or distribution. Within each computational cell $i$, the total cross-sectional power available $\left(P_{f l u x, i}\right)$ can be defined as the product of the average power density $\left(A P D_{i}\right)$, the water depth $\left(d_{i}\right)$ and the cross-sectional width $\left(w_{i}\right)$. The total available power $\left(P_{f l u x}\right)$ within a region is the combination of the individual $P_{f l u x, i}$ 's, and must be corrected with the Significant Impact Factor (SIF) in order to provide an estimation of the available extractable power:

$P_{\text {extr }}=P_{\text {flux }} \cdot \mathrm{SIF}=\mathrm{SIF} \cdot \sum_{i=1}^{N c} A P D_{i} d_{i} w_{i} \quad(\mathrm{~kW})$

Since the tidal stream energy converters are to be normal to the typical flow direction in the channel in order to ensure maximum efficiency, $w_{i}$ has been taken as the diagonal length of each computational cell (i.e., $w_{i}=\sqrt{\Delta x^{2}+\Delta y^{2}}$, and $\Delta x=\Delta y=150 \mathrm{~m}$ ). With this assumption, the flux method shows that, on average, 150.078 MW of power is available for extraction at Area 1, of which 22.512 MW can be tapped without exerting a significant impact on the environment; at Area 2, these values are very similar, with 149.600 MW of available power, and 22.440 MW of extractable power.

The maximum theoretical number of devices that can be supported in each of the Areas can be estimated from the ratio between 


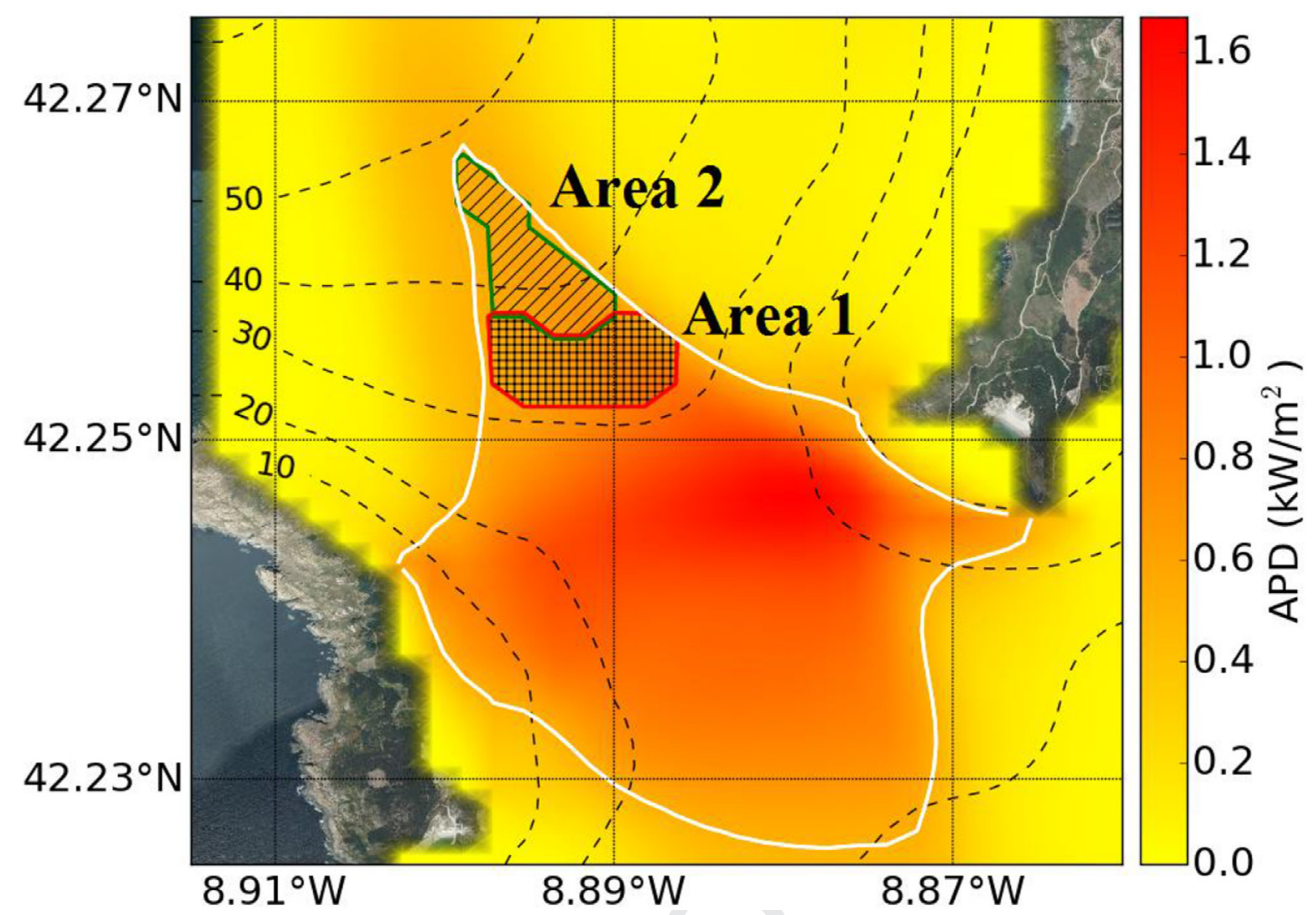

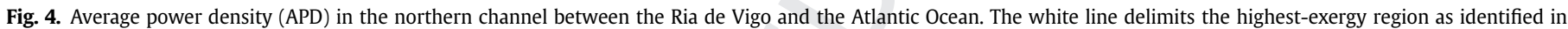

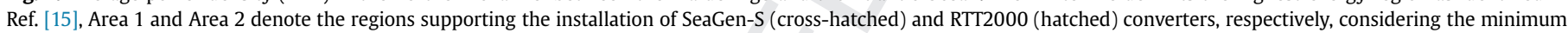
depth requirement.

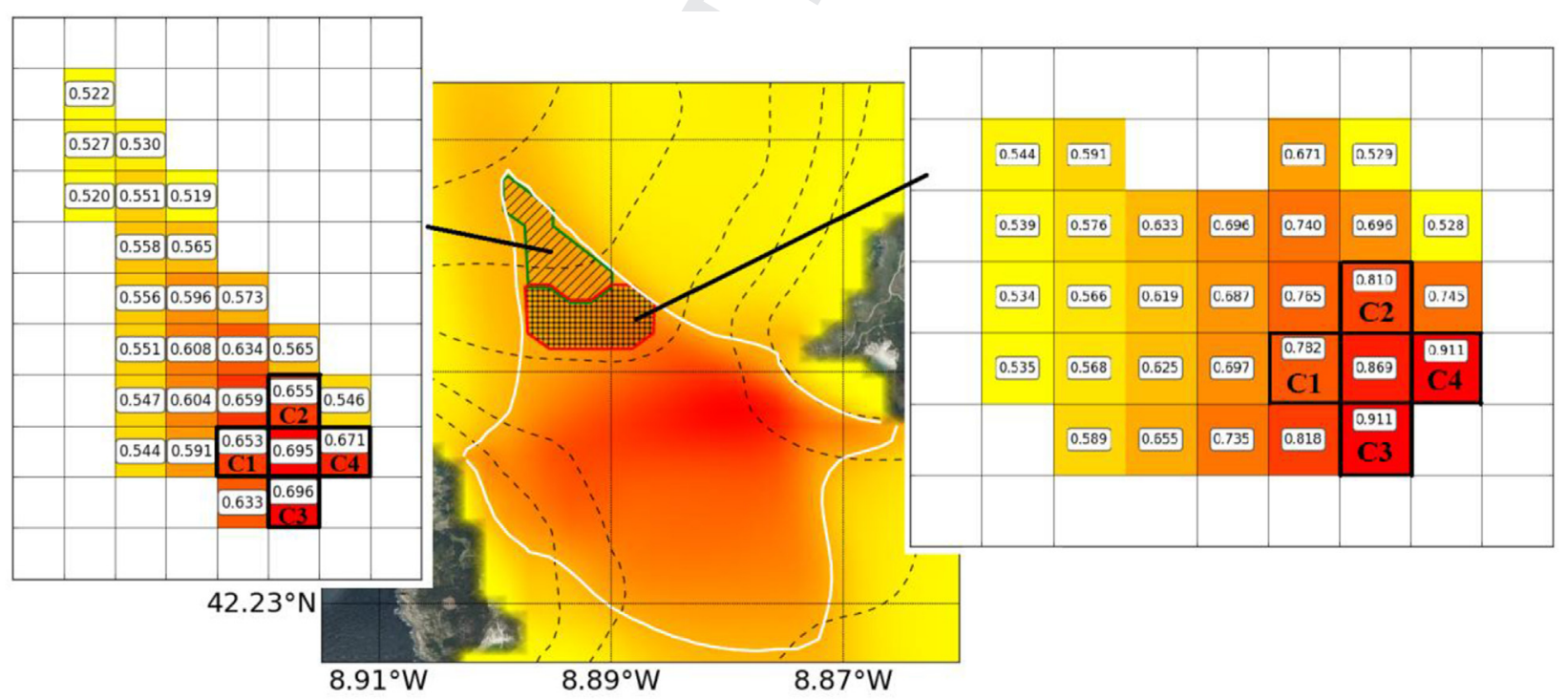

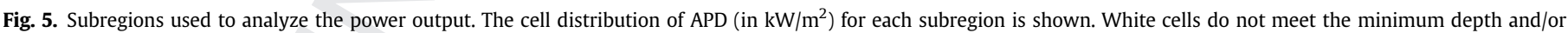
minimum APD $\left(0.5125 \mathrm{~kW} / \mathrm{m}^{2}\right)$ criteria. Computational cells labeled $\mathrm{C} 1$ to $\mathrm{C} 4$ delimit the most exergetic cells, and are those used in the local analysis.

the extractable power and the gross power extracted by a single turbine, obtained by combining the frequency histogram of the flow speed and the respective power curves. By operating on a cellby-cell basis, the results show that the extractable power at Area 1 is sufficient to feed up to 159 SeaGen-S converters, whereas Area 2 would require 276 RTT2000 generators to remove all of its extractable power.

However, the number of tidal stream energy converters that can be deployed is limited by physical considerations, such as the lateral and downstream separation necessary to avoid hydrodynamic interference between neighboring turbines (via the alteration of the flow patterns), as mentioned before. As an example, herein we consider a simple farm configuration with parallel rows of turbines perpendicular to the main flow direction, and keeping the aforementioned downstream separation between rows of $10 \phi$, and lateral inter-turbine distance of $2.5 \phi$. With this design, Area 1 allows for the deployment of 24 SeaGen-S turbines, and 26 RTT2000 devices could be installed in Area 2 (Fig. 6).

The power output of the turbines at each cell is obtained by combining the current speed frequency distribution (Fig. 7) with 

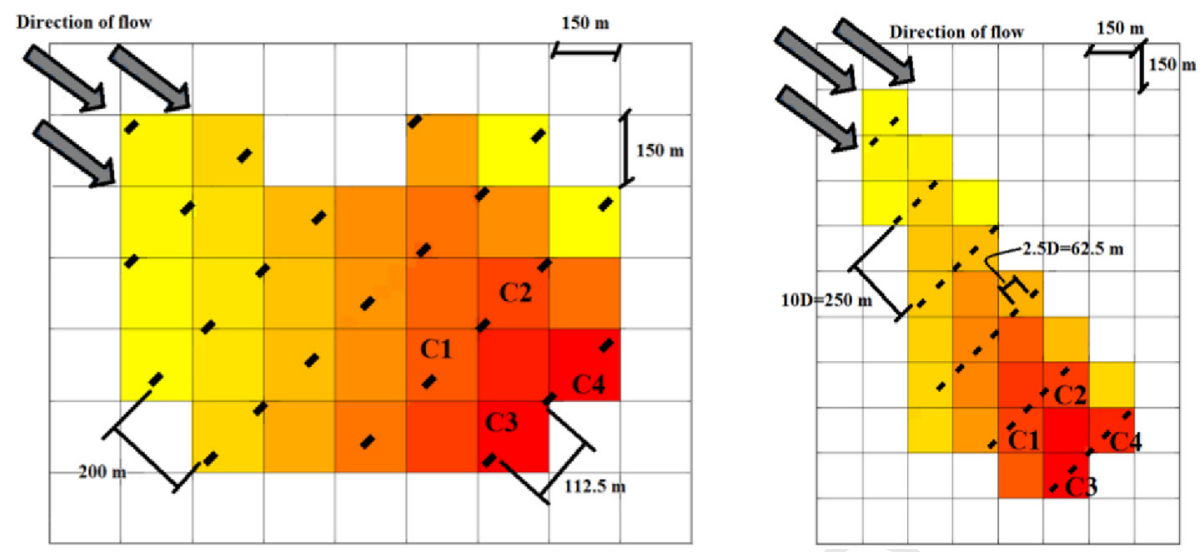

Fig. 6. Tidal converter distribution for the farm at Area 1 (SeaGen-S, left) and at Area 2 (RTT2000, right).

the power curve for each device. The frequency analysis reveals that, in both areas, the currents are below the cut-in threshold (i.e., $1.0 \mathrm{~m} / \mathrm{s}$ ) over $50 \%$ of the time. In Area 1 , the flow speed exceeds this value between $25 \%$ and $50 \%$ of the time, with smaller values at the edges of the Area, and larger ones along the central cells, whereas the exceedance time is lower in Area 2, ranging from $22 \%$ to $35 \%$. The flow direction (not shown) is mostly along a NNW-SSE direction (about $70 \%$ of the time), with smaller contributions from immediately neighboring sectors (between 10 and 20\%). This supports the selection of non-yawing turbines for this study. Fig. 8 shows the power output per turbine at each computational cell, highlighting the fact that the power extraction capacity of the SeaGen-S turbine is more efficient at the velocity ranges encountered in this area than that of the RTT2000 converter, thus leading to a smaller number of SeaGen-S converters required, although the amount of extractable energy is higher in Area 1 than it is in Area 2.

This analysis shows that the overall power output of the SeaGen-S farm would be of $3146.1 \mathrm{~kW}$, representing just $14 \%$ of the total extractable power; on the other hand, an RTT2000 farm with this configuration would supply $2090.9 \mathrm{~kW}$, barely $10 \%$ of the extractable power in Area 2 . Thus, the yearly power production for both farms would range between 27.6 GWh for the SeaGen-S turbines and slightly over 18.3 GWh for the RT2000 farm.

Assuming that the losses between the tidal stream farms and the main electricity distribution grid are of the order of $5 \%$ (e.g.
[48]) and considering that the average household electricity consumption in Spain in 2014 was of $3944 \mathrm{kWh} /$ year [49], these tidal stream energy farms could provide the necessary power for between 6638 homes (SeaGen-S farm) and 4411 households (RTT2000 farm). These results are comparable to the number of homes (approximately 6500) that are expected to be powered by several planned tidal stream farms in the UK, such as the Skerries Tidal Stream Array (6500 homes [50]) or the Sound of Islay Tidal Array (5400 households [51]).

The potential of the most energetic subregions of each area identified in Fig. 5 by cells $\mathrm{C} 1-\mathrm{C} 4$, is also assessed. These computational cells, extending over $0.09 \mathrm{~km}^{2}$, are centered on the cell with highest power potential. As before, the extractable power for these cells is calculated using the flux method, corrected with the $15 \% \mathrm{SIF}$, and is given in Table 2.

The frequency histograms for currents at cells C1 to C4 selected in Area 1 and Area 2 are shown in Fig. 9. The output power per turbine for each cell in terms of the current speed distribution is shown in Fig. 10, whereas the total output power per turbine and per cell is given in Table 2 .

The total number of these devices that would be necessary for the optimal extraction of tidal stream energy in Area 1 is 18, whereas 36 RTT2000 turbines would be required to extract the maximum amount of energy from the tidal stream in Area 2. Farms using this number of turbines would harness $87.8 \%$ of the available

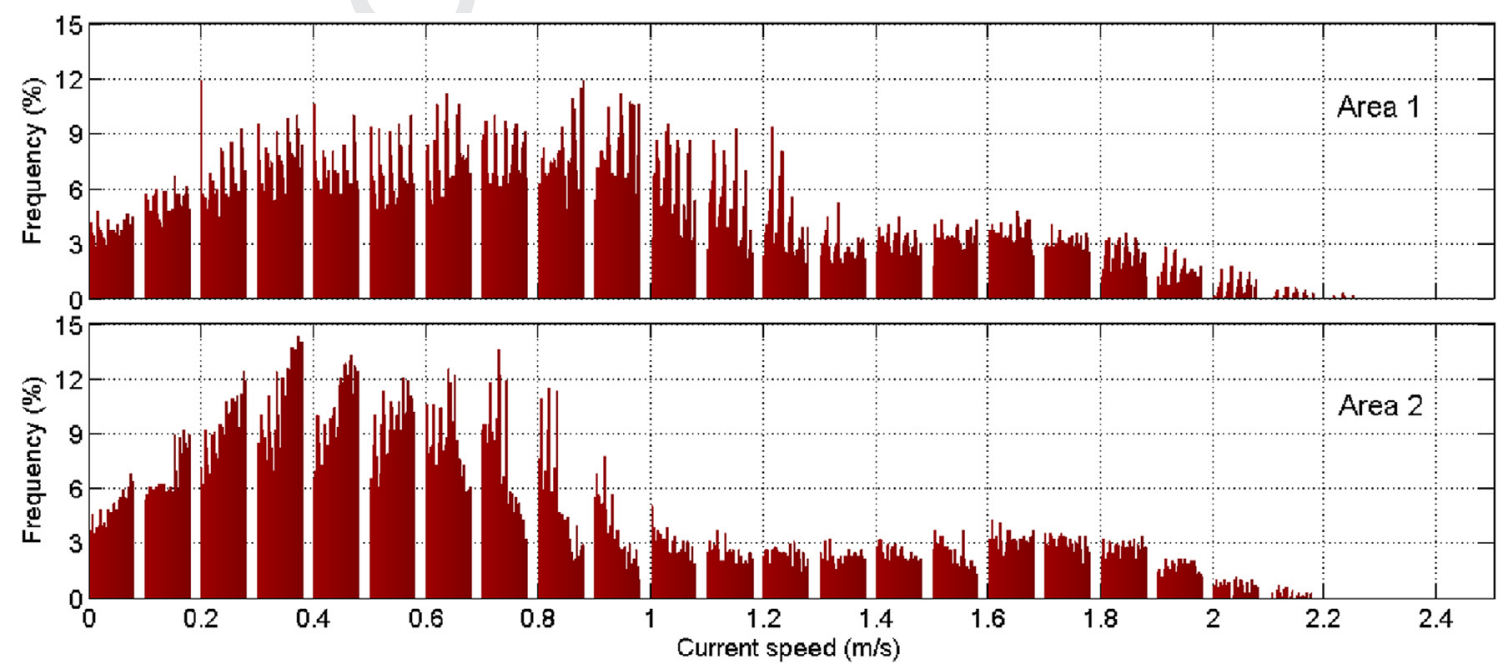

Fig. 7. Frequency histograms for the barotropic current speed at all the cells in Area 1 and Area 2. 


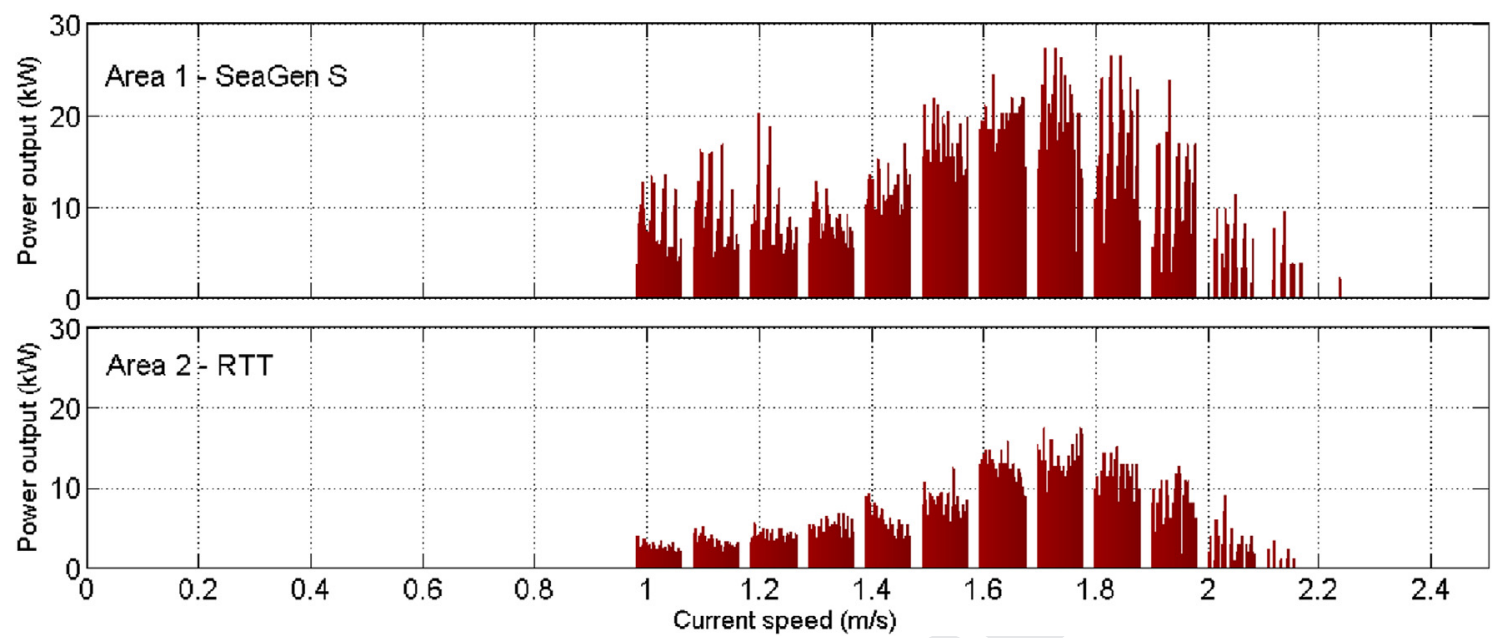

Fig. 8. Output power per turbine at each cell in Area 1 (SeaGen-S turbines) and Area 2 (RTT2000), in terms of the flow speed.

Table 2

Extractable power, extracted power per turbine and maximum number of turbines supported for each of the highlighted cells at both sites.

\begin{tabular}{|c|c|c|c|c|c|c|}
\hline \multirow[t]{2}{*}{ Cell } & \multicolumn{3}{|l|}{ Area 1 (SeaGen-S) } & \multicolumn{3}{|l|}{ Area 2 (RTT2000) } \\
\hline & $\begin{array}{l}\text { Extractable power } \\
(\mathrm{kW})\end{array}$ & $\begin{array}{l}\text { Power output per turbine } \\
(\mathrm{kW})\end{array}$ & $\begin{array}{l}\text { Maximum number of } \\
\text { turbines }\end{array}$ & $\begin{array}{l}\text { Extractable power } \\
(\mathrm{kW})\end{array}$ & $\begin{array}{l}\text { Power output per turbine } \\
(\mathrm{kW})\end{array}$ & $\begin{array}{l}\text { Maximum number of } \\
\text { turbines }\end{array}$ \\
\hline $\mathrm{C} 1$ & 838.51 & 157.34 & 5 & 794.45 & 85.85 & 9 \\
\hline $\mathrm{C} 2$ & 881.38 & 162.66 & 5 & 817.92 & 86.68 & 9 \\
\hline C3 & 910.60 & 188.28 & 4 & 819.04 & 90.58 & 9 \\
\hline $\mathrm{C} 4$ & 919.77 & 191.11 & 4 & 797.27 & 86.09 & 9 \\
\hline Total & 3550.3 & & 18 & 3228.7 & & 36 \\
\hline
\end{tabular}

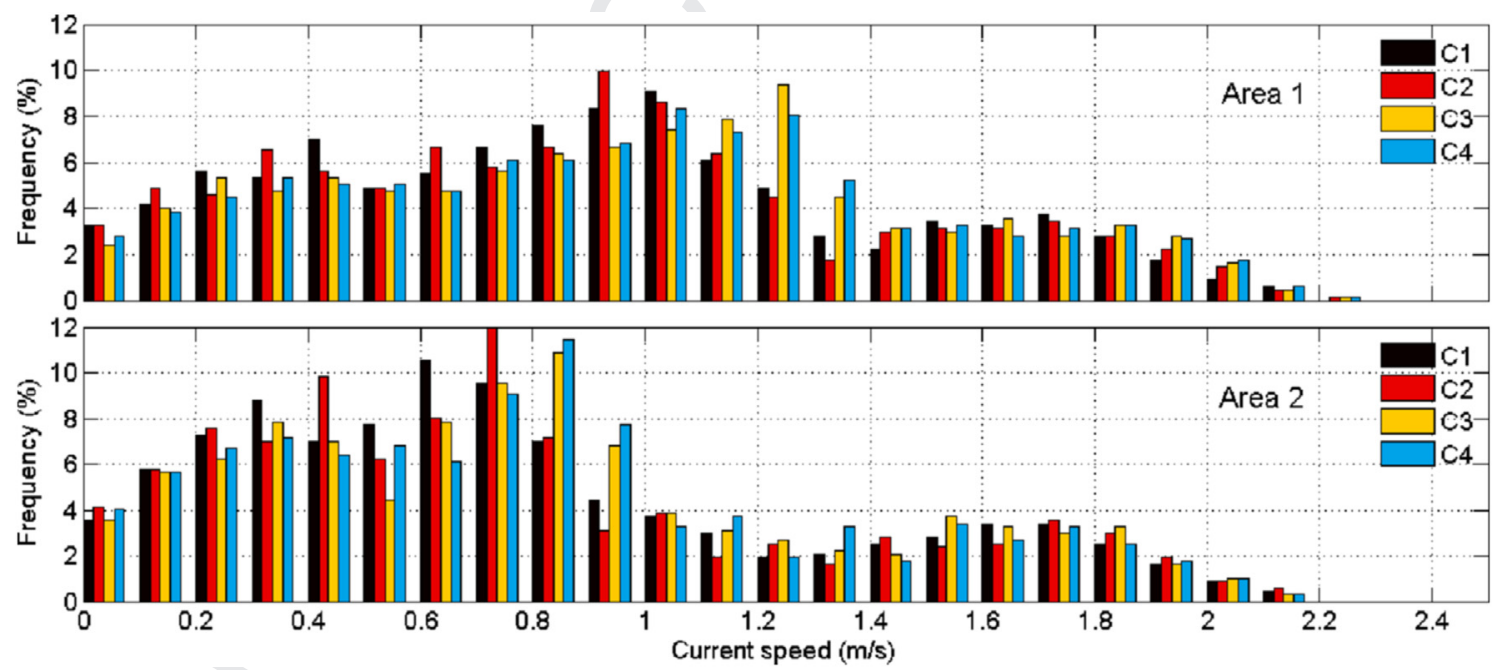

Fig. 9. Frequency histograms for the barotropic current speed at the highlighted cells in Area 1 and Area 2.

extractable energy in Area 1, and up to 97.5\% of the energy in Area 2.

Nevertheless, and maintaining the farm configuration defined above, each row of two computational cells would allow the deployment of 3 SeaGen-S turbines, or 4-5 RTT2000 generators. Considering the turbine output per cell given in Table 2, the SeaGen-S farm would output $1049 \mathrm{~kW}$, which represents just over $29.5 \%$ of the total extractable power; on the other hand, an RTT2000 farm with this configuration would supply $787 \mathrm{~kW}$, only $24 \%$ of the extractable power in Area 2. Thus, the yearly energy production for both farms would range between $9.19 \mathrm{GWh}$ for the
SeaGen-S turbines and slightly over 6.89 GWh for the RT2000 farm, powering between 2213 (SeaGen-S) and 1660 (RTT2000) households.

\section{Conclusions}

A zone with a high potential for the extraction of tidal stream energy has been previously identified close to the Ria de Vigo estuary. In this paper, the optimal location for the installation of a tidal energy converter farm in this area has been determined using 


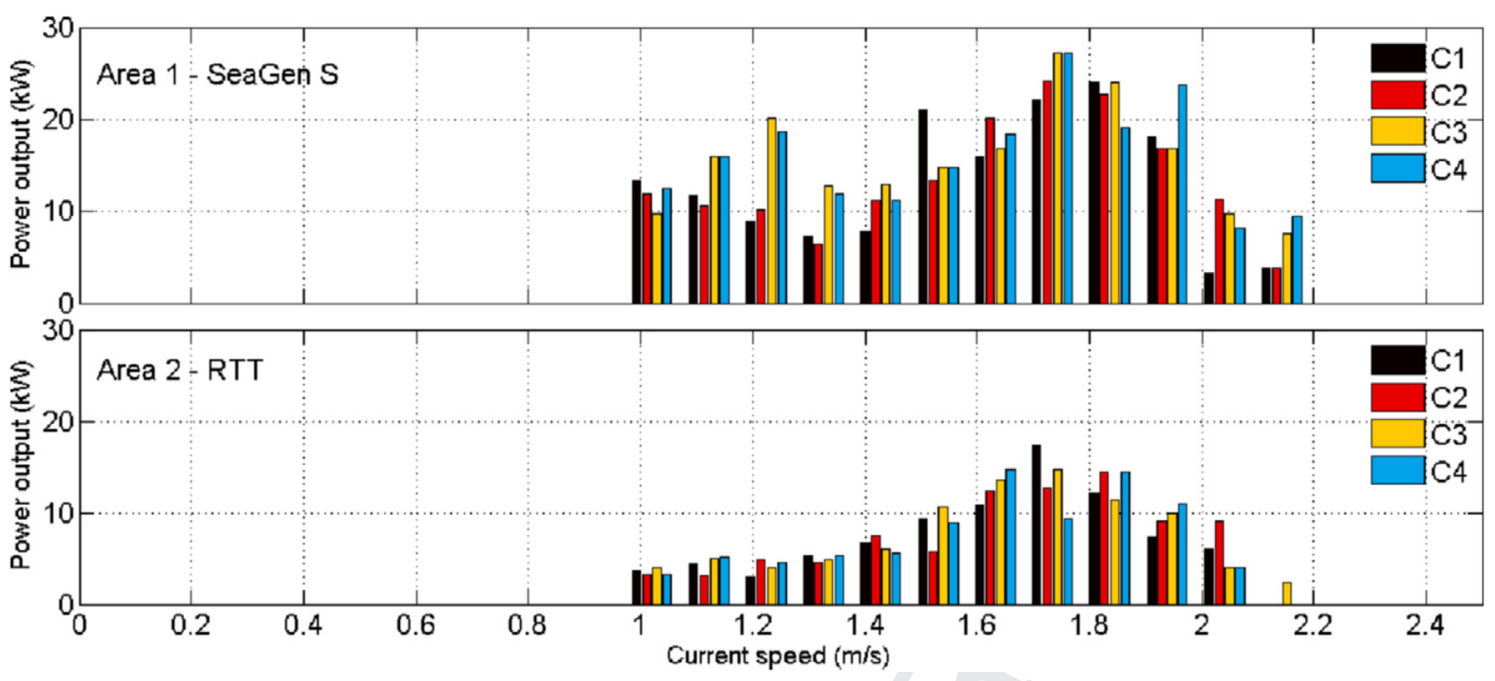

Fig. 10. Output power per turbine at each highlighted cell in Area 1 (SeaGen-S turbines) and Area 2 (RTT2000), in terms of the flow speed.

the spatial and temporal distribution of the tidal currents. The average power density associated to these flows has been assessed previously from the results of a 28-day long numerical simulation [15]. Since this location depends, amongst other factors, on the relation between the water depth and the size (diameter) of the converters, two different horizontal axis turbines have been considered for the sake of comparison: Lunar Energy's RTT2000, and MCT's SeaGen-S. The power curve of both turbines allows also estimating and comparing the power output that can be expected within this region.

Once the threshold for exploitable energy and waterdepth restrictions have been considered, only small areas seem suitable for the installation of a tidal farm. For the SeaGen-S device, this area extends over $0.7 \mathrm{~km}^{2}$, whereas it is slightly smaller $\left(0.6 \mathrm{~km}^{2}\right)$ for the RTT2000, since the latter requires deeper waters than the former. In spite of this, the annual energetic potential in these small areas is considerable, exceeding $181 \mathrm{MWh} / \mathrm{m}^{2}$ and $139 \mathrm{MWh} / \mathrm{m}^{2}$, respectively. The use of the flux method allows calculating the total power that could be extracted without exerting a significant impact on the environment. For Area 1 (SeaGen-S), and considering a $15 \%$ SIF, the mean hourly extractable power is $22.51 \mathrm{MW}$, and 22.44 MW for Area 2 (RTT2000). The inter-turbine spacing specifications required to optimize energy tapping and minimize environmental impact imply, however, that only a fraction of this potential can be actually extracted.

A simple-design farm extending over the selected Areas, with parallel rows of converters set perpendicularly to the main flow (channel) direction and complying with the lateral and downstream spacing conditions, serves to quantify this ratio. Whereas the total energy potential in the farm area is sufficient to feed 159 SeaGen-S (Area 1) and 276 RTT2000 (Area 2) turbines, space requirements reduce these numbers to only 24 SeaGen-S and 26 RTT2000 turbines. With these arrangements, the potential power output by the farms is between $10 \%$ and $15 \%$ of the available extractable power in the region. Even with these small ratios, the extracted power output is sufficient to fulfil the energy requirements of between 4411 homes (RTT2000 farm) and 6638 households (SeaGen-S farm). The extraction ratio increases to about $30 \%$ if only the most energetic location within each Area is considered, although in this case the number of powered homes is evidently smaller, between 2213 and 1660 for Area 1 and Area 2, respectively.

This study shows that, from a resource point of view, the Ria de
Vigo estuary has enough potential for the installation of tidal energy converters which could, in principle, power over 6600 homes. However, the number of turbines required to provide this output might render the full exploitation of the proposed area unpractical from an economic standpoint due to the large capital costs involved. Since these are largely site-specific, it is difficult to determine a typical installation cost. Although a detailed economic analysis has not been done, the figures provided in the introductory section suggest nevertheless that the scheme presented herein might not be cost-effective for the development of a commercial farm under current technological conditions. Still, it is expected that continuous research in -and improvement of - converter devices, experience and innovation should allow to reduce the economic costs of tidal energy harvesting in the future.

\section{Acknowledgments}

This study was funded by the research project "Desarrollo de una herramienta de alta resolución como soporte al diseño, colocación y explotación de instalaciones para energías marinas (DARDO)" (ref. ENE2012-38772-C02-02) funded by the Spanish Ministry of Economy and Competitiveness. The support of the Secretaria d'Universitats i Recerca del Dpt. d'Economia i Coneixement de la Generalitat de Catalunya (Ref.2014SGR1253) is also acknowledged.

\section{References}

[1] IEA. World energy outlook. Paris: International Energy Agency, OECD/IEA; 2014. 2014.

[2] Bentley RW. Global oil and gas depletion: an overview. Energy Policy 2002;30: 189-205.

[3] IPCC. In: Pachauri RK, Meyer LA, editors. “Climate change 2014: synthesis report. Contribution of working groups I, II and III to the fifth assessment report of the intergovernmental panel on climate change" [core writing team. Geneva, Switzerland: IPCC; 2014. 151 pp.

[4] O'Rourke F, Boyle F, Reynolds A. Tidal energy update 2009. App Energy 2010;87(2):398-409. http://dx.doi.org/10.1016/j.apenergy.2009.08.014.

[5] Brooks D. The hydrokinetic power resource in a tidal estuary: the Kennebec River of the central Maine coast. Renew Energy 2011;36:1492-501. http:/| dx.doi.org/10.1016/j.renene.2010.10.029.

[6] Xia J, Falconer RA, Lin B. Numerical model assessment of tidal stream energy resources in the Severn Estuary, UK. Proc Inst Mech Eng Part A J Power Energy 2010;224(7):969-83. http://dx.doi.org/10.1243/09576509JPE938.

[7] Draper S, Adcock T, Bothwick A, Houlsby G. Estimate of the tidal stream power resource of the Pentland Firth. Renew. Energy 2014;63:650-7. http:// dx.doi.org/10.1016/j.renene.2013.10.015.

[8] Karsten RH, McMillan JM, Lickley MJ, Haynes RD. Assessment of tidal current 
energy in the Minas passage, Bay of Fundy. Proc Inst Mech Eng Part A J Power Energy 2008;222(5):493-507. http://dx.doi.org/10.1243/09576509JPE555.

[9] Grabbe M, Lalander E, Lundin S, Leijon M. A review of the tidal current resource in Norway. Renew Sust Energy Rev 2009;13(8):1898-909. http:// dx.doi.org/10.1016/j.rser.2009.01.026.

[10] Rashid A. Status and potentials of tidal in-stream energy resources in the southern coasts of Iran: a case study. Renew Sust Energy Rev 2012;16: 6668-77. http://dx.doi.org/0.1016/j.rser.2012.08.010.

[11] Li D, Wang S, Yuan P. An overview of development of tidal current in China: energy resource conversion technology and opportunities. Renew Sust Energy Rev 2010;14:2896-905. http://dx.doi.org/0.1016/j.rser.2010.06.001.

[12] Byun D-S, Hart D, Jeong W-J. Tidal current energy resources off the south and west coasts of Korea: preliminary observation-derived estimates. Energies 2013;6:566-78. http://dx.doi.org/10.3390/en6020566.

[13] Carballo R, Iglesias G, Castro A. Numerical model evaluation of tidal stream energy resources in the Ría de Muros (NW Spain). Renew Energy 2009;34(6): $1517-24$.

[14] Iglesias G, Sánchez M, Carballo R, Fernández H. The TSE index - a new tool for selecting tidal stream sites in depth-limited regions. Renew Energy 2012;48: 350-7. http://dx.doi.org/10.1016/j.renene.2012.05.012.

[15] Mestres M, Griñó M, Sierra JP, Mösso C. Assessment of tidal current energy resources in the mesotidal Ria de Vigo (NW Spain). Renew Energy (submitted) 2016.

[16] EPRI. Tidal in stream energy conversion reports. 2006 [Online]. Available at: http://oceanenergy.epri.com/streamenergy.html [Accessed 11-Feb-2016].

[17] Aquaret. Case study - Race Rocks. 2006 [Online]. Available at: http://www. wisions.net/files/uploads/Aquaret_Race_Rocks.pdf [Accessed 11-Feb-2016].

[18] Fraenkel P. Next gen SeaGen. Mod Power Syst 2006;26(2):28.

[19] Ahmadian R, Falconer R. Assessment of array shape of tidal stream turbines on hydro-environmental impacts and power output. Renew Energy 2012;44: 318-27. http://dx.doi.org/10.1016/j.renene.2012.01.106.

[20] Ahmadian R, Falconer R, Bockelmann-Evans B. Far-field modelling of the hydro-environmental impact of tidal stream turbines. Renew Energy 2012;38(1):107-16. http://dx.doi.org/10.1016/j.renene.2011.07.005.

[21] Polagye B, Van Cleeve B, Copping A, Kirkendall K, editors. Environmental effects of tidal energy development. U.S. Dept. Commerce, NOAA Tech; 2011 p. 181. Memo. F/SPO-116.

[22] Gill A. Offshore renewable energy: ecological implications of generating electricity in the coastal zone. J Appl Energy 2005;42:605-15.

[23] Kadiri M, Ahmadian R, Bockelmann-Evans B, Rauen W, Falconer R. A review of potential water quality impacts of tidal renewable energy systems. Renew Sustain Energy Rev 2012;16(1):329-41. http://dx.doi.org/10.1016/ j.rser.2011.07.160.

[24] DOE. Report to congress on the potential environmental effects of marine and hydrokinetic energy technologies: prepared in response to the energy independence act of 2007. In: Section 633 (B), wind \& power program, energy efficiency \& renewable energy. U.S. Dept. of Energy; 2009.

[25] Bryden IG, Couch SJ, Owen A, Melville A. Tidal current resource assessment. Proc Instn Mech Engrs, Part A J Power Energy 2007;221(2):125-35.

[26] Hardistry J. The tidal stream power curve: a case study. Energy Power Eng 2012;4:132-6. http://dx.doi.org/10.4236/epe.2012.43018.

[27] Li Y. On the definition of the power coefficient of tidal current turbines and efficiency of tidal current turbine farms. Renew Energy 2014;68:868-75.

[28] Myers LE, Bahaj AS. An experimental investigation simulating flow effects in first generation marine current energy converter arrays. Renew Energy 2012;37(1):28-36.

[29] Legrand C. Assessment of tidal energy resource, marine renewable energy guides. The European Marine Energy Centre Ltd.; 2009. p. 60.

[30] Divett TA. Optimising design of large tidal energy arrays in channels: layout and turbine tuning for maximum power capture using large eddy simulations with adaptive mesh PhD Thesis. New Zealand: University of Otago; 2014. 335 pp. Available from: http://hdl.handle.net/10523/4995 [Accessed 19-Jan-2016].

[31] Martín B. Dynamic description of the circulation in two rias baixas: Vigo and
Pontevedra. PhD thesis. Spain: University of Vigo; 2003. 182 pp (in Spanish).

[32] Nogueira E, Pérez FF, Ríos AF. Seasonal patterns and long-term trends in an estuarine upwelling ecosystem (Ría de Vigo, NW Spain). Estuar Coast Shelf Sci 1997;44:285-300.

[33] Montero P. Hydrodynamic study of the Ría de Vigo using a finite volumes model. PhD Thesis. Spain: University of Santiago de Compostela; 1999. 174 pp (in Spanish).

[34] Álvarez I, deCastro M, Gómez-Gesteira M, Prego R. Inter- and intra-annual variability of the salinity and temperature evolution in the Galician Rías Baixas - ocean boundary (northwest Spain). J Geophys Res 2005;110(C04008). http://dx.doi.org/10.1029/2004JC002504.

[35] Mestres M, Sierra JP. Meteorological and oceanographic characterization of the Ria de Vigo. Research Report RR-LIM/AHC-11-1. Barcelona: UPC-BarcelonaTech; 2011. 46 pp (in Spanish).

[36] Myers L, Bahaj AS. Simulated electrical power potential harnessed by marine current turbine arrays in the Alderney Race. Renew Energy 2005;30(11): 1713-31.

[37] Ramos V, Carballo R, Álvarez M, Sánchez M, Iglesias G. Assessment of the impacts of high tidal stream energy through high-resolution numerical modelling. Energy 2013;61:541-54.

[38] Griñó M. Power generation from tidal currents. Application to Ria de Vigo. Minor Thesis. Technical University of Catalunya-BarcelonaTech; 2015. 81 pp.

[39] Bedard R, Previsic M, Siddiqui O, Hagerman G, Robinson M. Tidal in stream energy conversion devices. 2005. p. 185. EPRI report TP-004 NA Final.

[40] MacEnri J, Reed M, Thiringer T. Power quality performance of the tidal energy converter. In: SeaGen. Proc. Int. Conf. On ocean. Rotterdam (The Netherlands: Offshore and Arctic Engineering; 2011. paper no. 49549, 8 pp.

[41] Marine Current Turbines. SeaGen-S system description. 2016 [Online]. Available at: http://www.Marineturbines.com/SeaGen-Products/SeaGen-S [Accessed 03-Feb-2016].

[42] Marine Current Turbines. "Sea-Gen-S 2MW", marine current turbines, MCT product brochure. 2013.

[43] Koroneos K, Spachos T, Moussiopoulos N. Exergy analysis of renewable energy sources. Renew Energy 2003;28:295-310.

[44] Black, Veatch. "UK, europe, and global tidal energy resource assessment", marine energy challenge report No. 107799/D/2100/05/1. London: Carbon Trust; 2004.

[45] Bryden IG, Melville GT. Choosing and evaluating sites for tidal current development. Proc Instn Mech Engrs, Part A J Power Energy 2004;218: 567-77.

[46] Bryden IG, Grinsted T, Melville GT. Assessing the potential of a simple tidal channel to deliver useful energy. Appl Ocean Res 2004;26:198-204.

[47] Hagerman G, Polagye B, Bedard R, Previsic M. Methodology for estimating tidal current energy resources and power production by tidal in-stream energy conversion (TISEC) devices. 2006. p. 55. EPRI report TP-001 NA Rev 3.

[48] Santos M, Salcedo F, Ben Haim D, Mendia JL, Ricci P, Villate JL, et al. Integrating wave and tidal current power: case studies through modelling and simulation. 2011. OES-IA Annex III Technical Report, OES-IA Document No: T0331. Available at: http://www.iea-oceans.org.

[49] World Energy Council. Average electricity consumption per electrified household. 2015 [Online]. Available at: https://www.wec-indicators.enerdata. eu/household-electricity-use.html [Accessed 16-Jan-2016].

[50] Marine Current Turbines. Skerries tidal stream array: environmental impact assessment scoping report. Rev 3. 2006 [Online]. Available at: http://www. marineenergypembrokeshire.co.uk/wp-content/uploads/2012/10/TheSkerriesTidal-Stream-Array-Environmental-Statement-NTS.pdf [Accessed 14Apr-2016]

[51] Scottish Power Renewables. Cable route environmental information. 2013 [Online], Available at: http://www.scottishpowerrenewables.com/userfiles/ file/Sound\%20of\%20Isaly\%20Demonstration\%20Tidal\%20Array\%20Cable\% 20Route\%20Environmental\%20Report_May\%202013.pdf [Accessed 16-Apr2016]. 